Article

\title{
Horseradish Peroxidase-Decorated Artificial Viral Capsid Constructed from $\beta$-Annulus Peptide via Interaction between His-Tag and Ni-NTA
}

\author{
Kazunori Matsuura ${ }^{1,2, *(\mathbb{D})}$, Yuriko Shiomi ${ }^{1}$, Toshihumi Mizuta ${ }^{3}$ and Hiroshi Inaba ${ }^{1,2}$ \\ 1 Department of Chemistry and Biotechnology, Graduate School of Engineering, Tottori University, \\ Tottori 680-8552, Japan; perinko23@gmail.com (Y.S.); hinaba@tottori-u.ac.jp (H.I.) \\ 2 Centre for Research on Green Sustainable Chemistry, Tottori University, Tottori 680-8552, Japan \\ 3 Technical Department, Tottori University, Tottori 680-8552, Japan; mizuta@tottori-u.ac.jp \\ * Correspondence: ma2ra-k@tottori-u.ac.jp; Tel.: +81-857-31-5262
}

Received: 28 September 2020; Accepted: 12 November 2020; Published: 13 November 2020

\begin{abstract}
Artificial construction of spherical protein assemblies has attracted considerable attention due to its potential use in nanocontainers, nanocarriers, and nanoreactors. In this work, we demonstrate a novel strategy to construct peptide nanocapsules (artificial viral capsids) decorated with enzymes via interactions between His-tag and Ni-NTA. A $\beta$-annulus peptide derived from the tomato bushy stunt virus was modified with Ni-NTA at the C-terminus, which is directed toward the exterior surface of the artificial viral capsid. The $\beta$-annulus peptide bearing Ni-NTA at the C-terminus self-assembled into capsids of about $50 \mathrm{~nm}$ in diameter. The Ni-NTA-displayed capsids were complexed with recombinant horseradish peroxidase (HRP) with a C-terminal His-tag which was expressed in Escherichia coli. The $\beta$-annulus peptide-HRP complex formed spherical assemblies whose sizes were $30-90 \mathrm{~nm}$, with the $\zeta$-potential revealing that the HRP was decorated on the outer surface of the capsid.
\end{abstract}

Keywords: artificial viral capsid; self-assembly; $\beta$-annulus peptide; horseradish peroxidase; nanocapsule; surface decoration

\section{Introduction}

Natural supramolecular protein nanocapsules such as viral capsids [1,2], clathrin [3], carboxysomes [4], encapsulins [5,6], lumazine synthases [7], and ferritins [8,9] play pivotal roles in many biological processes associated with compartments, transports, and reactions. Natural and engineered protein nanocapsules with a discrete size and hollow nanospace have been used as biomedical carriers and reactors for artificial nanomaterials [6-15]. Advances in the molecular design of proteins/peptides mimicking natural nanocapsules have made it possible to create nanocapsules with functions comparable to or surpassing those of natural ones [16-22]. One of the main strategies in constructing artificial protein/peptide nanocapusles is by self-assembly of amphiphilic molecules. For example, Nolte et al. demonstrated that protein nanocapsules can be self-assembled from "giant amphiphiles" consisting of horseradish peroxidase (HRP) and polystyrene, which are used in peroxidase-based enzymatic cascade reaction systems [23-25]. Hayashi et al. developed an artificial light-harvesting protein nanocapsule self-assembled from hexameric hemoproteins modified with poly(N-isopropylacrylamide) [26]. Another strategy to construct artificial nanocapsules is to utilize the interactions among secondary structures in the self-assembling protein/peptide subunits [27-32]. For example, Kawakami et al. designed polyhedral protein nanocapusles constructed from fusion proteins consisting of pentamer- and dimer-forming coiled-coil units [29]. Marsh and coworkers developed highly stable icosahedral protein nanocapsules self-assembled from trimeric protein 
subunits bearing rigid coiled-coils [30]. Although the construction strategy of artificial protein/peptide nanocapsules has progressed, the chemical functionalization of nanocapsules remains a challenge.

We have previously reported that a 24-mer $\beta$-annulus peptide derived from tomato bushy stunt virus capsid spontaneously formed hollow nanoassemblies, "artificial viral capsids" [33], which can encapsulate various guests such as anionic dyes, DNAs, quantum dots, and His-tagged proteins [19,34-38]. Furthermore, modification of the C-terminus, which is expected to be directed toward the exterior surface of the capsid, enabled modification of the outer surface of artificial viral capsids with gold nanoparticles, coiled-coil peptides, single-stranded DNAs, human serum albumin, and ribonuclease S [39-44]. These decorations onto artificial viral capsids were based on covalent bonds between $\beta$-annulus peptide and functional molecules or reconstruction of proteins. In this study, we developed a simple, general method to decorate proteins bearing tags onto the artificial viral capsids. That is, we constructed HRP-decorated artificial viral capsids via specific interactions between the His-tag connected to the C-terminus of HRP and Ni-NTA displayed on the capsid surface (Figures 1 and 2).
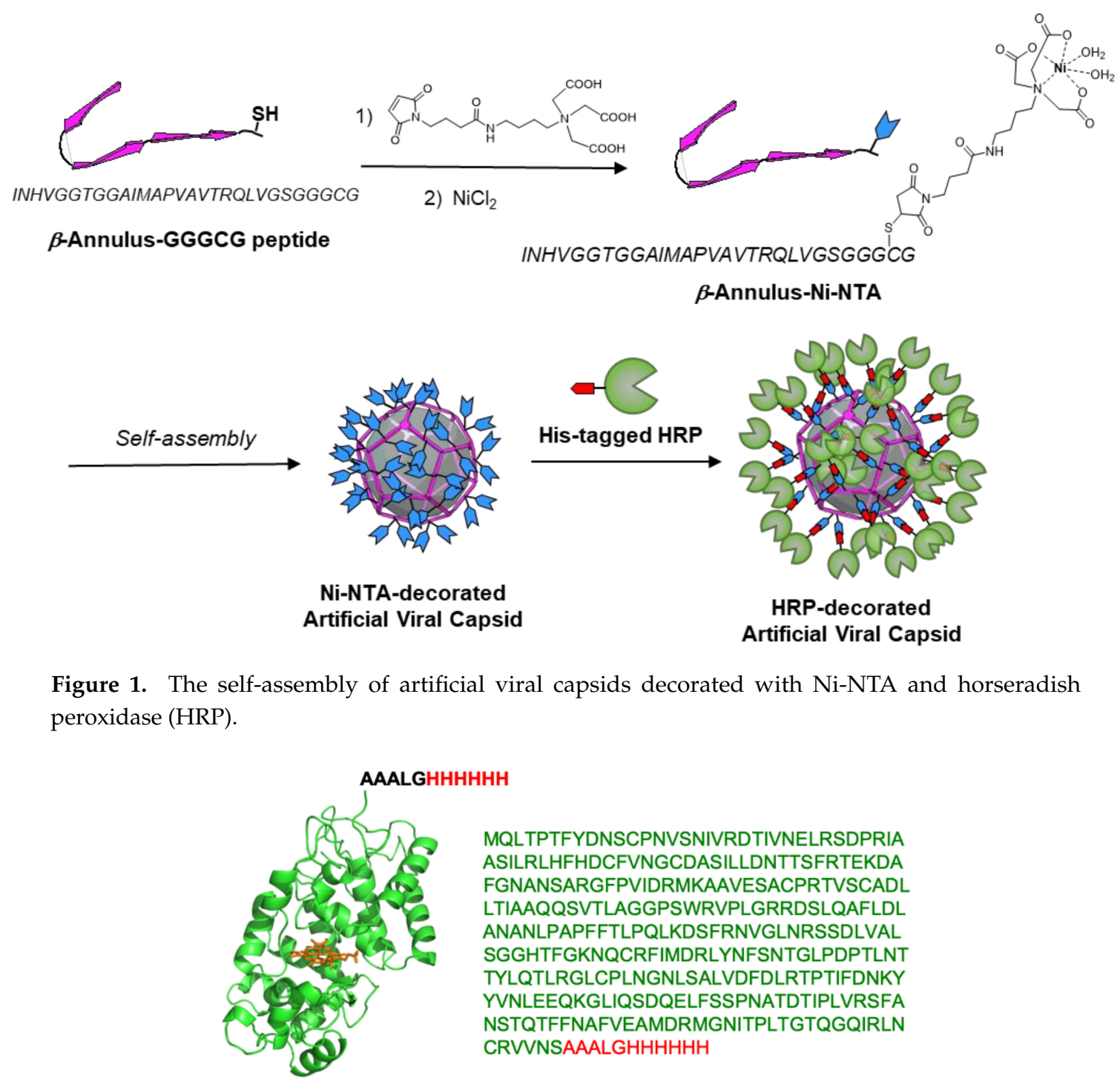

Figure 2. Structure and amino acid sequence of His-tagged HRP. 


\section{Materials and Methods}

\subsection{General}

Chemical reagents obtained from commercial sources were used without further purification. Ultrapure water $(>18 \mathrm{M} \Omega \mathrm{cm}$ ) purified using a Millipore Purification System (Milli-Q water) was used as a solvent for the peptides. Reverse phase HPLC was performed at room temperature using a Shimadzu LC-6AD liquid chromatography system equipped with Inertsil WP300 C4 (GL Science) columns (250 $\times 4.6 \mathrm{~mm}$ or $250 \times 20 \mathrm{~mm})$ and a UV/Vis detector $(220 \mathrm{~nm}$, Shimadzu SPD-10AVvp). MALDI-TOF mass spectra were measured using an Autoflex T2 instrument (Bruker Daltonics) in linear/positive mode with a matrix ( $\alpha$-cyano-4-hydroxy cinnamic acid ( $\alpha$-CHCA) or sinapinic acid) circular dichroism (CD) spectra were measured using a JASCO J-820 spectrophotometer equipped with a Peltier-type thermostatic cell holder at $25^{\circ} \mathrm{C}$ in a $1.0 \mathrm{~mm}$ quartz cell.

\subsection{Preparetion of His-Tagged HRP}

A nucleotide fragment of HRP was amplified using standard PCR methods. The HRP fragment was cloned into a pET23a vector, with its His-tag and additional sequence (AAALGHHHHHH) located at the C-terminus, using the In-Fusion cloning kit (TaKaRa Bio). The $\mathrm{pET} 23 \mathrm{a}$ vector encoding His-tagged HRP was transformed into an Escherichia coli strain (BLR(DE3)). Bacterial cells were spread on Luria-Bertani (LB) agar containing $50 \mu \mathrm{g} / \mathrm{mL}$ ampicillin and grown at $37^{\circ} \mathrm{C}$ overnight. A single transformant colony was grown in LB medium at $37^{\circ} \mathrm{C}$ overnight. The culture was diluted 100 -fold by the addition of fresh LB medium and grown to an optical density (OD) of 0.5 , and the culture was subsequently incubated with $1 \mathrm{mM}$ isopropyl $\beta$-D-1-thiogalactopyranoside (IPTG) at $37^{\circ} \mathrm{C}$. After incubation for $3 \mathrm{~h}$, cells were harvested by centrifugation at $8000 \mathrm{rpm}$ for $10 \mathrm{~min}$. The cell pellets were suspended in buffer A (50 mM Tris- $\mathrm{HCl} \mathrm{pH} \mathrm{8.0,1} \mathrm{mM} \mathrm{ethylenediaminetetraacetic} \mathrm{acid} \mathrm{(EDTA),} 10 \mathrm{mM}$ dithiothreitol (DTT)). The cells were lysed by sonication. Three centrifugations at $14,500 \mathrm{rpm}$ for $20 \mathrm{~min}$ were carried out. After the first centrifugation, the pellets were washed with buffer A supplemented with $2 \mathrm{M}$ urea. After the second centrifugation, the inclusion body was solubilized in buffer $\mathrm{B}(50 \mathrm{mM}$ Tris- $\mathrm{HCl} \mathrm{pH}$ 8.0, $1 \mathrm{mM}$ DTT, $6 \mathrm{M}$ urea). After the third centrifugation, His-tagged apo-HRP in the supernatant was refolded according to reported procedures [45]. The refolded His-tagged HRP was purified by a HisTrap HP column (GE Healthcare) using an elution buffer (10 mM Tris- $\mathrm{HCl} \mathrm{pH}$ 7.4, $0.15 \mathrm{M} \mathrm{NaCl}, 200 \mathrm{mM}$ imidazole, 2M Urea). The His-tagged apo-HRP was characterized using SDS-PAGE and MALDI-TOF-MS. The eluted sample $(0.4 \mathrm{mg} / \mathrm{mL})$ was mixed with hemin (2 equivalents) in $10 \mathrm{mM}$ Tris-HCl pH 7.2 and stirred for $40 \mathrm{~min}$. The sample was dialyzed (1 kDa cut-off) against $10 \mathrm{mM}$ Tris- $\mathrm{HCl}$ pH 7.2 overnight. The His-tag HRP obtained was characterized using MALDI-TOF-MS.

\subsection{Preparation of $\beta$-Annulus Peptide C-Terminus-Modified with Ni-NTA}

The $\beta$-annulus-GGGCG peptide H-Ile-Asn(Trt)-His(Trt)-Val-Gly-Gly-Thr(tBu)-Ile-Met-AlaPro-Val-Ala-Val-Thr(tBu)-Arg(Pbf)-Gln(Trt)-Leu-Val-Gly-Ser(tBu)-Gly-Gly-Gly-Cys(Trt)-Gly-Alko-PEG resin was synthesized using standard Fmoc-based coupling reactions (4 equivalents. Fmoc-amino acids) at a $0.125 \mathrm{mmol}$ scale on commercially available Fmoc-Gly-Alko-PEG resin $(0.22 \mathrm{mmol} / \mathrm{g}$, Watanabe Chemical Ind. Ltd.). The deprotection of Fmoc groups was carried out with $20 \%$ piperidine in $\mathrm{N}, \mathrm{N}$-dimethylformamide (DMF) at room temperature for $15 \mathrm{~min}$. Coupling reactions of the Fmoc-protected amino acids (4 equivalents) were carried out for $90 \mathrm{~min}$ at room temperature using four equivalents of (1-cyano-2-ethoxy-2-oxoethylidenaminooxy) dimethylamino-morpholinocarbenium hexafluorophosphate (COMU) in $N$-methylpyrrolidone (NMP) and eight equivalents of diisopropylamine (DIPEA) in NMP. Progression of the coupling reactions and deprotection of the Fmoc group was confirmed by a 2,4,6-trinitrobenzenesulfonic acid (TNBS) and chloranil test kit (Tokyo Chemical Industry Co., Ltd.). The peptidyl resin was washed with NMP. The peptide was cleaved from the resin and deprotected with a cleavage cocktail of trifluoroacetic acid (TFA)/1,2-ethanedithiol/triisopropylsilane/thioanisole/water [8.15/0.25/0.10/0.50/0.50 (mL),] at room 
temperature for $3 \mathrm{~h}$. After filtration to remove resins, the filtrates were concentrated in vacuo. The peptide was precipitated with methyl tert-butyl ether and the supernatant was decanted. After three washes with methyl tert-butyl ether, the peptide was freeze-dried to give $228 \mathrm{mg}$ of a colorless solid (66\% yield). The reverse-phase HPLC of the crude peptide was eluted with a linear gradient of $\mathrm{CH}_{3} \mathrm{CN} /$ water containing $0.1 \%$ TFA (26/74 to 29/71 over $120 \mathrm{~min}$ ) and showed one peak at $23 \mathrm{~min}$. The isolated yield was $24 \%$. MALDI-TOF MS (matrix: $\alpha$-CHCA): $m / z=2637[\mathrm{M}]^{+}$.

A $1.0 \mathrm{mM}$ aqueous solution of $\beta$-annulus-GGGCG peptide in $10 \mathrm{mM}$ Tris-HCl buffer (pH 7.2, $0.1 \mathrm{~mL}$ ) was mixed with a $2.5 \mathrm{mM}$ aqueous solution $(0.1 \mathrm{~mL})$ of maleimido-C3-NTA (Dojindo Laboratories), and then the mixture was incubated for $15 \mathrm{~h}$ at room temperature. The mixture was purified using reversed-phase HPLC and eluted with a linear gradient of acetonitrile/water (26/74 to 29/71 over $120 \mathrm{~min}$ ) containing $0.1 \%$ TFA to provide pure $\beta$-annulus-NTA peptide (isolated yield $42 \%$ ). MALDI-TOF-MS (matrix: $\alpha$-CHCA): $m / z=3064[\mathrm{M}]^{+}$.

The purified $\beta$-annulus-NTA peptide was dissolved in $10 \mathrm{mM}$ Tris- $\mathrm{HCl}$ buffer to prepare a $5.0 \mathrm{mM}$ aqueous solution. Subsequently, an aliquot of $\mathrm{NiCl}_{2}$ solution in $10 \mathrm{mM}$ Tris- $\mathrm{HCl}$ buffer was added to the peptide solution to become [peptide] $=\left[\mathrm{Ni}^{2+}\right]=2.5 \mathrm{mM}$. Formation of the $\beta$-annulus-Ni-NTA complex was confirmed by MALDI-TOF-MS (matrix: $\alpha$-CHCA): $\mathrm{m} / \mathrm{z}=3123[\mathrm{M}]^{+}$.

\subsection{Complexation of His-Tagged HRP with Ni-NTA-Modified $\beta$-Annulus Peptide}

Stock solutions ( $0.1 \mathrm{mM}$ ) of $\beta$-annulus-Ni-NTA were prepared by dissolution in $10 \mathrm{mM}$ Tris- $\mathrm{HCl}$ buffer ( $\mathrm{pH}$ 7.2). The complexes of $\beta$-annulus-Ni-NTA with His-tagged HRP were prepared by mixing with aqueous solutions of His-tagged HRP in the same buffer and then incubating at $25^{\circ} \mathrm{C}$ for $24 \mathrm{~h}$.

\subsection{Dynamic Light Scattering (DLS) and $\zeta$-Potential}

DLS was measured using a Zetasizer Nano ZS (MALVERN) instrument with an incident $\mathrm{He}-\mathrm{Ne}$ laser $(633 \mathrm{~nm})$ at $25{ }^{\circ} \mathrm{C} . \mathrm{G}(\tau)$ (correlation times of the scattered light intensities) were measured several times and then the diffusion coefficient were calculated from the mean values of $G(\tau)$. Using the Stokes-Einstein equation, hydrodynamic diameters of the scattering particles were calculated. Zeta potentials of $\beta$-annulus-Ni-NTA, His-tagged HRP, and their mixture at $25 \mu \mathrm{M}$ in $10 \mathrm{mM}$ Tris-HCl buffer ( $\mathrm{pH}$ 7.2) were measured at $25^{\circ} \mathrm{C}$ using the same instrument with a DT1061 clear disposable zeta cell.

\subsection{Transmission Electron Microscopy (TEM)}

Aliquots $(3 \mu \mathrm{L})$ of the samples were applied to C-SMART Hydrophilic TEM grids(ALLIANCE Biosystems Inc) for one min. Then, the droplet was removed using filter paper. Subsequently, the TEM grids were placed into a staining aqueous solution, $2 \%$ phosphotungstic acid $\left[\mathrm{Na}_{3}\left(\mathrm{PW}_{12} \mathrm{O}_{40}\right)\left(\mathrm{H}_{2} \mathrm{O}\right)_{n}\right]$ $(3 \mu \mathrm{L})$, for one min, and then removed. After the sample-loaded TEM grids were dried in vacuo, they were observed using TEM (JEOL JEM 1400 Plus) using $80 \mathrm{kV}$ accelerating voltage.

\subsection{HRP Activity}

The specific HRP activity was evaluated by a method adapted from the literature [46]. A solution $(350 \mu \mathrm{L})$ of 4-aminoantipyrine $(25 \mathrm{mM})$ and phenol $(17 \mathrm{mM})$ in $0.2 \mathrm{M}$ potassium phosphate buffer $(\mathrm{pH}$ 7.0) and an aqueous solution ( $375 \mu \mathrm{L})$ of hydrogen peroxide $(17 \mathrm{mM})$ in Milli-Q water was added to a quartz cell (path length: $1 \mathrm{~cm}$ ). After incubation for $4 \mathrm{~min}$ at $25^{\circ} \mathrm{C}$, the HRP-decorated artificial viral capsid was added to the quartz cell (final concentration of HRP: $25 \mu \mathrm{M}$ ). The absorbance change was measured at $510 \mathrm{~nm}$ over $250 \mathrm{~s}$. The specific enzyme activity was calculated from the slope of the absorbance change divided by the concentration of protein in $\mathrm{mg} / \mathrm{mL}$. 


\section{Results}

\subsection{Construction of an Artificial Viral Capsid Modified with Ni-NTA at the Surface}

To construct an artificial viral capsid modified with Ni-NTA at the surface, we designed a Cys-containing $\beta$-annulus peptide at the C-terminal side ( $\beta$-annulus-GGGCG peptide) which was directed toward the exterior of the capsid [34,39,42]. The $\beta$-annulus-GGGCG peptide (INHVGGTGGAIMAPVAVTRQLVGSGGGCG) was synthesized by standard Fmoc-protected solid-phase method, purified by reversed-phase HPLC, and confirmed by MALDI-TOF-MS $(\mathrm{m} / \mathrm{z}=2637)$. The Cys of the peptide was reacted with maleimido-C3-NTA to obtain $\beta$-annulus peptide modified with NTA at the C-terminus. After the $\beta$-annulus-NTA peptide was purified by reversed-phase HPLC and analyzed by MALDI-TOF-MS $(m / z=3064)$, the peptide was complexed with $\mathrm{NiCl}_{2}$ to obtain $\beta$-annulus-Ni-NTA peptide, which was analyzed by MALDI-TOF-MS $(m / z=3123)$.

Size distribution obtained from DLS and TEM images of the solutions of the $\beta$-annulus-Ni-NTA peptide in $10 \mathrm{mM}$ Tris- $\mathrm{HCl}$ buffer ( $\mathrm{pH}$ 7.2) revealed the formation of spherical assemblies of approximately $50 \mathrm{~nm}$ in diameter (Figure 3). The diameter is comparable to the diameter of unmodified [33] and modified artificial viral capsids [35,38-43] self-assembled from $\beta$-annulus peptide derivatives, which indicates that Ni-NTA modification of the $\beta$-annulus peptide at the C-terminus minimally affected the self-assembling behavior. The relatively broad size distribution observed by DLS of $25 \mu \mathrm{M}$ Ni-NTA-modified $\beta$-annulus peptide might be caused by relatively unstable assembly of the peptide with dynamic equilibrium at a lower concentration. The concentration dependence on the scattering intensity obtained from DLS showed that the critical aggregation concentration (CAC) of the C-terminus-Ni-NTA modified $\beta$-annulus peptide in a Tris- $\mathrm{HCl}$ buffer at $25^{\circ} \mathrm{C}$ was approximately $10 \mu \mathrm{M}$ (Figure 4 ), which is comparable to the CAC of an unmodified $\beta$-annulus peptide (25 $\mu \mathrm{M})$ [33], but higher than that of the N-terminus-Ni-NTA modified $\beta$-annulus peptide $(0.053 \mu \mathrm{M})$ [38].

(a)
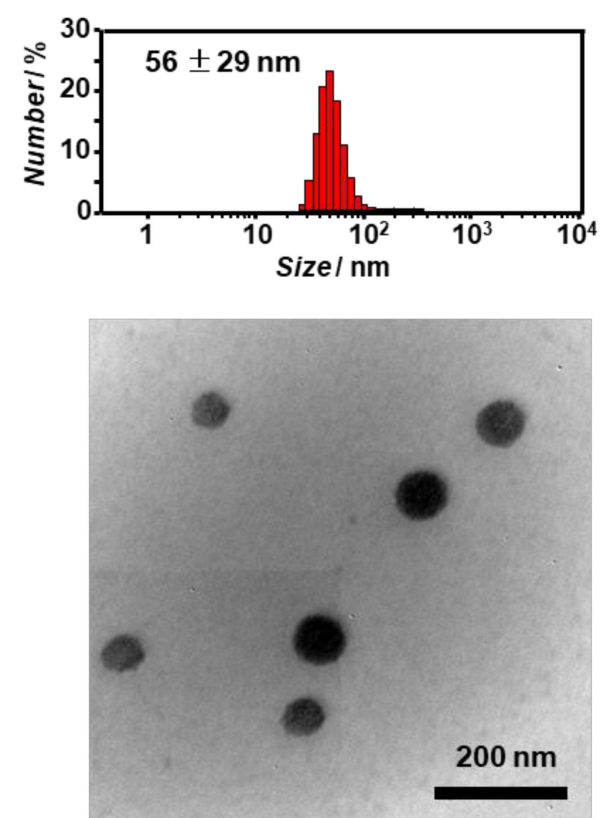

(b)
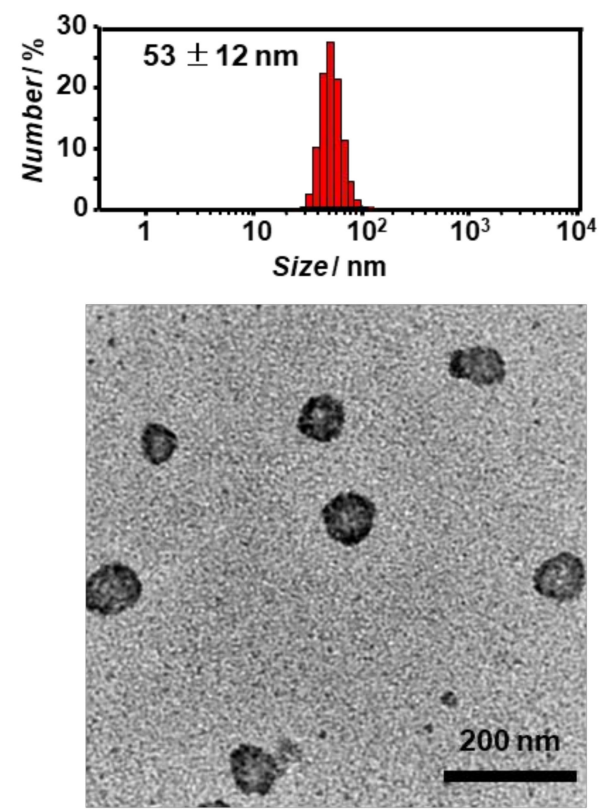

Figure 3. Size distributions obtained from Dynamic Light Scattering (DLS) at $25^{\circ} \mathrm{C}$ and transmission electron microscopy (TEM) images for solutions of (a) $25 \mu \mathrm{M}$ and (b) $50 \mu \mathrm{M} \beta$-annulus peptide modified with Ni-NTA at the C-terminus in a $10 \mathrm{mM}$ Tris-HCl buffer ( $\mathrm{pH} 7.2)$. 


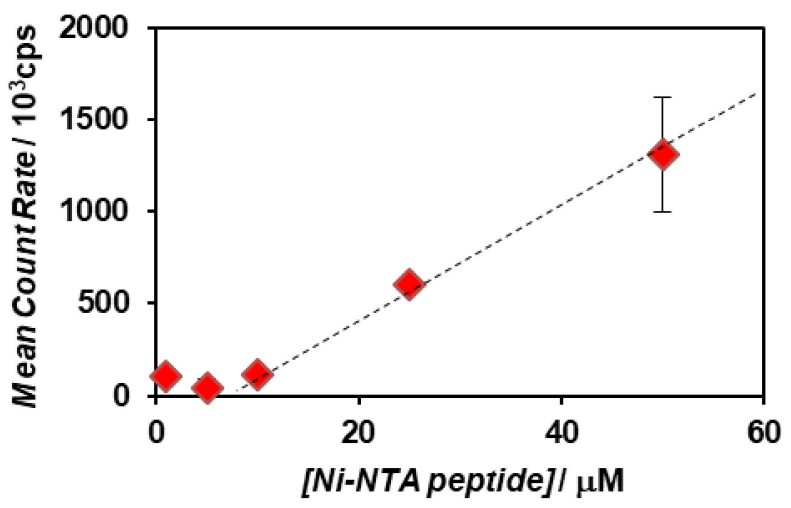

Figure 4. Effect of the concentration of $\beta$-annulus peptide modified with Ni-NTA on scattering intensity determined by DLS at $25^{\circ} \mathrm{C}$ in a $10 \mathrm{mM}$ Tris- $\mathrm{HCl}$ buffer ( $\left.\mathrm{pH} 7.2\right)$.

\subsection{Preparation of His-Tagged HRP}

Recombinant horseradish peroxidase with a C-terminal His6 tag (His-tagged HRP, Figure 2) was expressed from the pET23a vector encoding His-tagged HRP in an E. coli BLR (DE3) expression system as reported in the literature (Figure 5) [45]. For protein expression and purification, the transformants were cultured in LB media, and expression of the plasmid was induced by IPTG. After the disruption of cells by sonication, the inclusion body was solubilized in a buffer containing $6 \mathrm{M}$ urea. The refolded His-tagged apo-HRP was purified by a Ni-NTA column eluted with imidazole. The SDS-PAGE revealed the formation and isolation of $32 \mathrm{kDa}$ His-tagged apo-HRP (Figure 6a). His-tagged HRP was formed by reconstruction of His-tagged apo-HRP with hemin and confirmed by MALDI-TOF-MS (Figure $6 \mathrm{~b}$ ). The theoretical molecular mass of His-tagged HRP reconstructed with hemin is calculated to be 35,768 Da based on the amino acids sequence. Considering the broad peak (35,029 Da) observed by MALDI-TOF-MS, we decided that the mass was almost comparable to the theoretical value. The UV-vis spectrum of hemin was red-shifted by reconstruction to produce a spectrum similar to commercially available HRP (Figure 7), indicating a successful reconstruction of His-tagged HRP. The slight difference of maximum absorption wavelength of His-tagged HRP $(410 \mathrm{~nm})$ and commercially available HRP (403 nm) might be caused by difference of environment around hemin in HRP.

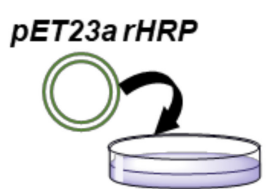

E. coli BLR(DE3) expression

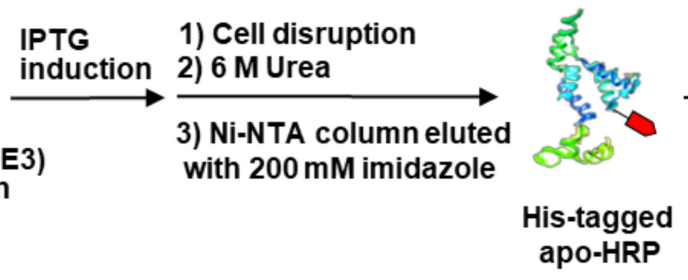

Figure 5. Schematic illustration of the preparation of His-tagged HRP. 
(a)

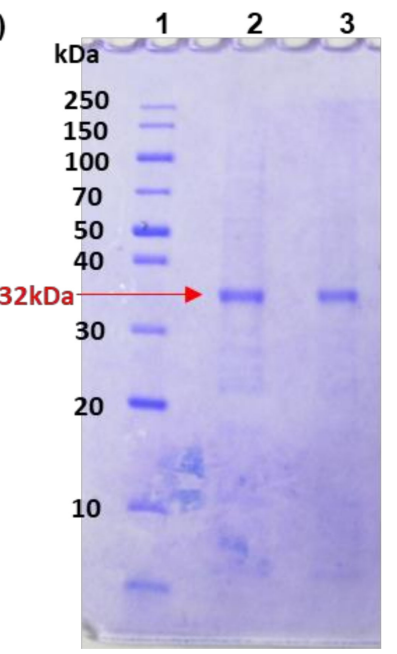

(b)

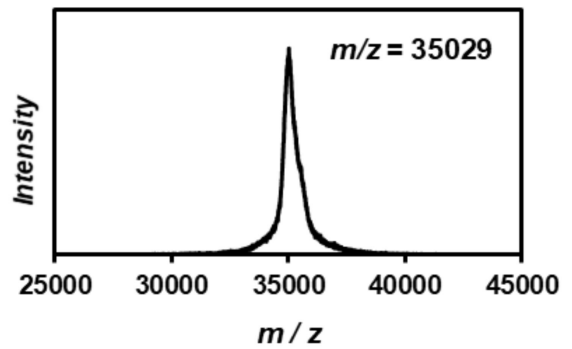

Figure 6. (a) SDS-PAGE of His-tagged apo-HRP (Lane 2: $0.4 \mathrm{mg} / \mathrm{mL}$, Lane 3: $0.2 \mathrm{mg} / \mathrm{mL}$ ) and (b) MALDI-TOF-MS of His-tagged HRP.



Figure 7. UV-Vis spectra of (a) hemin ( $24 \mathrm{mM})$, (b) His-tagged HRP $(0.2 \mathrm{mg} / \mathrm{mL})$, and (c) commercially available HRP $(0.2 \mathrm{mg} / \mathrm{mL})$ in $10 \mathrm{mM}$ Tris- $\mathrm{HCl}$ buffer $(\mathrm{pH} 7.2)$.

\subsection{Construction of HRP-Decorated Artificial Viral Capsid}

The HRP-decorated artificial viral capsids were constructed by incubating solutions of the $\beta$-annulus-Ni-NTA peptide with solutions of His-tagged HRP in $10 \mathrm{mM}$ Tris-HCl buffer (pH 7.2) at $25^{\circ} \mathrm{C}$ for $24 \mathrm{~h}$. The DLS of the equimolar mixture of $\beta$-annulus-Ni-NTA peptide and His-tagged HRP showed average hydrodynamic diameters of approximately $30 \mathrm{~nm}$ (Figure 8), which were smaller than those of $\beta$-annulus-Ni-NTA peptide assemblies (Figure 3). It is probable that the spherical structures were shrunk by complexation with His-tagged HRP on Ni-NTA-modified artificial viral capsids. TEM images of the aqueous solutions showed the formation of spherical assemblies with diameters of 30-90 nm (Figure 8). To confirm decoration on the exterior of Ni-NTA modified artificial viral capsids by HRP, we measured the $\zeta$-potentials of the Ni-NTA-modified capsid, His-tagged HRP, and their equimolar mixture at $\mathrm{pH} 7.2$ (Figure 9). The $\zeta$-potential of the Ni-NTA-modified capsid was $-13.9 \pm 5.3 \mathrm{mV}$, whereas that of the equimolar mixture of Ni-NTA-modified capsid and His-tagged HRP was $-21.0 \pm 5.8 \mathrm{mV}$, which is close to that of His-tagged HRP alone, $-24.6 \pm 4.5 \mathrm{mV}$. These results indicate that His-tagged HRP was decorated on the exterior of the Ni-NTA-modified artificial viral capsid.

The specific enzyme activity of the HRP-decorated artificial viral capsid was evaluated by colorimetric assay using 4-aminoantipyrine, phenol, and hydrogen peroxide as substrates [46]. 
The specific enzyme activity of intact His-tagged HRP in potassium phosphate buffer (pH 7.0) at $25{ }^{\circ} \mathrm{C}$ was 1.63 Units/mg, whereas that of HRP-decorated artificial viral capsid was $0.238 \mathrm{Units} / \mathrm{mg}$ under the same conditions (Figure 10). This decline of HRP activity might be caused by crowding of HRP on the capsid surface and concomitant structural changes. This result is in contrast to the retained activity of RNase S-decorated artificial viral capsids [43].

(a)
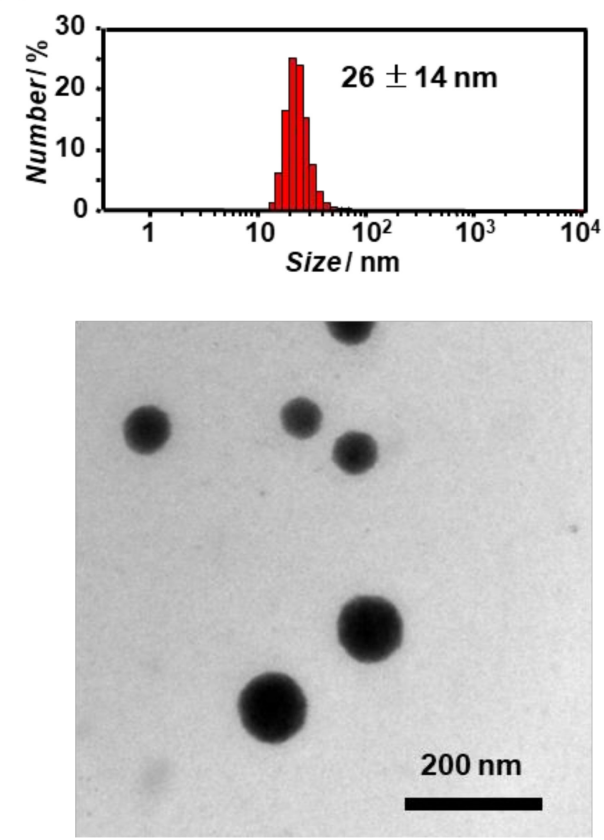

(b)
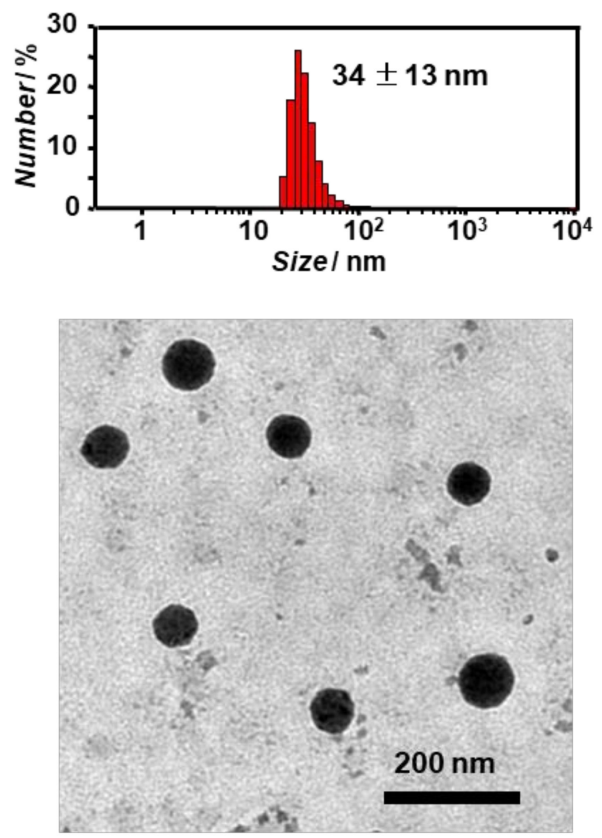

Figure 8. Size distributions obtained from DLS at $25^{\circ} \mathrm{C}$ and TEM images for solutions of (a) $50 \mu \mathrm{M}$

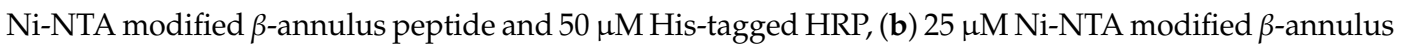
peptide and $25 \mu \mathrm{M}$ His-tagged HRP in $10 \mathrm{mM}$ Tris- $\mathrm{HCl}$ buffer ( $\mathrm{pH}$ 7.2).



Figure 9. $\zeta$-Potentials of (a) the assembly of $25 \mu \mathrm{M}$ Ni-NTA modified $\beta$-annulus peptide, (b) $25 \mu \mathrm{M}$ His-tagged HRP, and (c) their 1:1 mixture in $10 \mathrm{mM}$ Tris- $\mathrm{HCl}$ buffer (pH 7.2). 
(a)

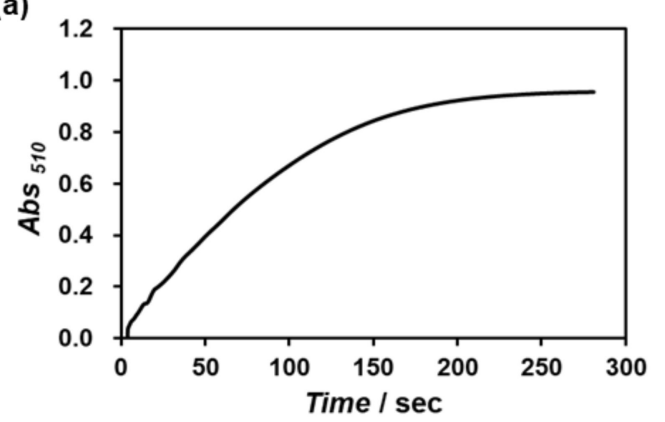

(b)

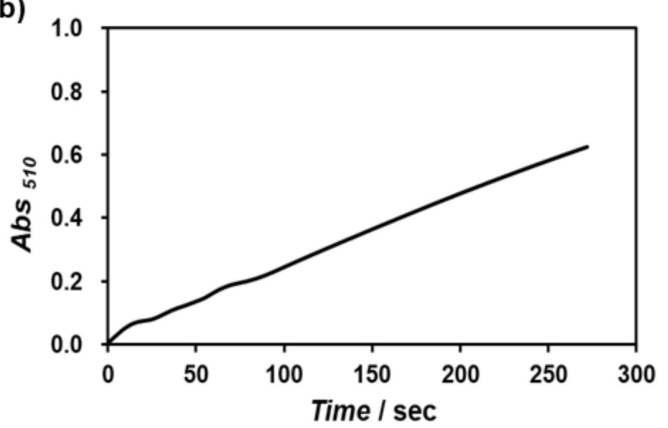

Figure 10. Time courses of absorbance increase at $510 \mathrm{~nm}$ due to the enzymatic reaction of (a) His-tagged HRP $(11.4 \mu \mathrm{M})$ and $(\mathbf{b})$ HRP-decorated artificial viral capsid $(25 \mu \mathrm{M})$ using 4-aminoantipyrine, phenol, and hydrogen peroxide as substrates in the phosphate buffer $(\mathrm{pH} 7.0)$ at $25^{\circ} \mathrm{C}$.

\section{Discussion}

We demonstrated that $\beta$-annulus peptide bearing Ni-NTA at the C-terminus self-assembled into artificial viral capsids and complexed with recombinant His-tagged HRP. The HRP-decorated artificial viral capsids with sizes of 30-90 nm showed peroxidase activity, but it was lower than that of intact His-tagged HRP. Nolte and coworkers also reported that the activity of HRP-polystyrene assembly was significantly decreased compared to that of intact HRP [23]. Highly dense packing of HRP on the surface of nano-assembly might result in partial thermal denaturation to decrease the activity. However, Morii and coworkers reported a surprising enhancement of activity of dense-packed assembly of carbonic anhydrase on DNA origami scaffolds [47]. They proposed that the entropic force of water increases local substrate or cofactor concentration within the domain confined between enzyme surfaces, thus accelerating the reaction. Thus, we believe that rational design of proper spatial arrangement of enzymes on the surface of an artificial viral capsid will enable the creation of highly active enzyme-decorated capsids.

Compared to artificial protein assemblies previously reported [27-32], the strategy presented is simple and general, because it can be constructed from only a 29-residue peptide and easily available His-tagged proteins. Because it can be modified with multiple types of enzymes, the HRP-decorated artificial viral capsids would be applied to a platform for cascade reaction systems such as glucoseoxidase-peroxidase cascade system. Therefore, it can be used to decorate other His-tagged proteins onto artificial viral capsids. We envisage the construction of artificial viral capsids decorated with various proteins, which may be useful as a platform for vaccines and membraneless organelles such as artificial carboxysome.

\section{Conclusions}

We succeeded in constructing artificial spherical assembly decorated with active HRP via interactions between His-tagged HRP and Ni-NTA-modified $\beta$-annulus peptide. The DLS, TEM, and $\zeta$-potential of the assembly revealed the formation of HRP-decorated capsids of 30-90 nm in diameter. Although the peroxidase activity of the assembly was decreased compared to that of intact His-tagged HRP, there is room for improvement of molecular design of enzyme-decorated capsid.

Author Contributions: Conceptualization, K.M.; methodology, T.M. and H.I.; investigation, Y.S. and T.M.; writing, K.M. and H.I.; visualization, Y.S.; supervision, K.M.; funding acquisition, K.M. All authors have read and agreed to the published version of the manuscript.

Funding: This research was funded by a Grant-in-Aid for Scientific Research on Innovative Areas "Chemistry for Multimolecular Crowding Biosystems" (grant number: JP18H04558) and a Grant-in-Aid for Scientific Research (B) (grant number: JP18H02089).

Conflicts of Interest: The authors declare no conflict of interest. 


\section{References}

1. Harper, D.R. Viruses: Biology, Applications, and Control, Garland Science, 2nd ed.; Taylor \& Francis Group: Oxfordshire, UK, 2012.

2. Mateu, M.G. (Ed.) Structure and Physics of Viruses; Springer: Berlin/Heidelberg, Germany, 2013.

3. Brodsky, F.M. Diversity of clathrin function: New tricks for an old protein. Annu. Rev. Cell Dev. Biol. 2012, 28, 309-336. [CrossRef] [PubMed]

4. Yeates, T.O.; Kerfeld, C.A.; Heinhorst, S.; Cannon, G.C.; Shively, J.M. Protein-based organelles in bacteria: Carboxysomes and related microcompartments. Nat. Rev. Microbiol. 2008, 6, 681-691. [CrossRef] [PubMed]

5. Giessen, T.W.; Silver, P.A. Widespread distribution of encapsulin nanocompartments reveals functional diversity. Nat. Microbiol. 2017, 2, 17029. [CrossRef] [PubMed]

6. Gabashvili, A.N.; Chmelyuk, N.S.; Efremova, M.V.; Malinovskaya, J.A.; Semkina, A.S.; Abakumov, M.A. Encapsulins-Bacterial protein nanocompartments: Structure, properties, and application. Biomolecules 2020, 10, 966. [CrossRef]

7. Azuma, Y.; Edwardson, T.G.W.; Hilvert, D. Tailoring lumazine synthase assemblies for bionanotechnology. Chem. Soc. Rev. 2018, 47, 3543-3557. [CrossRef]

8. Jutz, G.; van Rijn, P.; Miranda, B.S.; Böker, A. Ferritin: A versatile building block for bionanotechnology. Chem. Rev. 2015, 115, 1653-1701. [CrossRef]

9. Ueno, T.; Tabe, H.; Tanaka, Y. Artificial metalloenzymes constructed from hierarchically-assembled proteins. Chem. Asian J. 2013, 8, 1646-1660. [CrossRef] [PubMed]

10. Khudyakov, Y.; Pumpens, P. (Eds.) Viral Nanotechnology; CRC Press: Boca Raton, FL, USA, 2016.

11. Wen, A.M.; Steinmetz, N.F. Design of virus-based nanomaterials for medicine, biotechnology, and energy. Chem. Soc. Rev. 2016, 45, 4074-4126. [CrossRef] [PubMed]

12. Van Rijn, P.; Schirhagl, R. Viruses, artificial viruses and virus-based structures for biomedical applications. Adv. Healthcare Mater. 2016, 5, 1386-1400. [CrossRef] [PubMed]

13. Bhaskar, S.; Lim, S. Engineering protein nanocages as carriers for biomedical applications. NPG Asia Mater. 2017, 9, e371. [CrossRef]

14. Ren, H.; Zhu, S.; Zheng, G. Nanoreactor design based on self-assembling protein nanocages. Int. J. Mol. Sci. 2019, 20, 592. [CrossRef] [PubMed]

15. Maity, B.; Fujita, K.; Ueno, T. Use of the confined spaces of apo-ferritin and virus capsids as nanoreactors for catalytic reactions. Curr. Opin. Chem. Biol. 2015, 25, 88-97. [CrossRef] [PubMed]

16. Matsuurua, K. Rational design of self-assembled proteins and peptides for nano- and micro-sized architectures. RSC Adv. 2014, 4, 2942-2953. [CrossRef]

17. De Santis, E.; Ryadnov, M.G. Peptide self-assembly for nanomaterials: The old new kid on the block. Chem. Soc. Rev. 2015, 44, 8288-8300. [CrossRef]

18. Luo, Q.; Hou, C.; Bai, Y.; Wang, R.; Liu, J. Protein assembly: Versatile approaches to construct highly ordered nanostructures. Chem. Rev. 2016, 116, 13571-13632. [CrossRef]

19. Matsuura, K. Synthetic approaches to construct viral capsid-like spherical nanomaterials. Chem. Commun. 2018, 54, 8944-8959. [CrossRef]

20. Kuan, S.L.; Bergamini, F.R.G.; Weil, T. Functional protein nanostructures: A chemical toolbox. Chem. Soc. Rev. 2018, 47, 9069-9105. [CrossRef]

21. Lou, S.; Wang, X.; Yu, Z.; Shi, L. Peptide tectonics: Encoded structural complementarity dictates programmable self-assembly. Adv. Sci. 2019, 6, 1802043. [CrossRef]

22. Hamley, I.W. Protein assemblies: Nature-inspired and designed nanostructures. Biomacromolecules 2019, 20, 1829-1848. [CrossRef]

23. Boerakker, M.J.; Hannink, J.M.; Bomans, P.H.H.; Frederik, P.M.; Nolte, R.J.M.; Meijer, E.M.; Sommerdijk, N.A.J.M. Giant amphiphiles by cofactor reconstitution. Angew. Chem. Int. Ed. 2002, 41, 4239-4241. [CrossRef]

24. Reynhout, I.C.; Cornelissen, J.J.L.M.; Nolte, R.J.M. Self-assembled architectures from biohybrid triblock copolymers. J. Am. Chem. Soc. 2007, 129, 2327-2332. [CrossRef] [PubMed]

25. Delaittre, G.; Reynhout, I.C.; Cornelissen, J.J.L.M.; Nolte, R.J.M. Cascade reactions in an all-enzyme nanoreactor. Chem. Eur. J. 2009, 15, 12600-12603. [CrossRef] [PubMed] 
26. Hirayama, S.; Oohora, K.; Uchihashi, T.; Hayashi, T. Thermoresponsive micellar assembly constructed from a hexameric hemoprotein modified with poly(N-isopropylacrylamide) toward an artificial light-harvesting system. J. Am. Chem. Soc. 2020, 142, 1822-1831. [CrossRef] [PubMed]

27. Fletcher, J.M.; Harniman, R.L.; Barnes, F.R.H.; Boyle, A.L.; Collins, A.; Mantell, J.; Sharp, T.H.; Antognozzi, M.; Booth, P.J.; Linden, N.; et al. Self-assembling cages from coiled-coil peptide modules. Science 2013, 340, 595-599. [CrossRef]

28. Ross, J.F.; Bridges, A.; Fletcher, J.M.; Shoemark, D.; Alibhai, D.; Bray, H.E.V.; Beesley, J.L.; Dawson, W.M.; Hodgson, L.R.; Mantell, J.; et al. Decorating self-assembled peptide cages with proteins. ACS Nano 2017, 11, 7901-7914. [CrossRef]

29. Kawakami, N.; Kondo, H.; Matsuzawa, Y.; Hayasaka, K.; Nasu, E.; Sasahara, K.; Arai, R.; Miyamoto, K. Design of hollow protein nanoparticles with modifiable interior and exterior surfaces. Angew. Chem. Int. Ed. 2018, 57, 12400-12404. [CrossRef]

30. Cristie-David, A.S.; Chen, J.; Nowak, D.B.; Bondy, A.L.; Sun, K.; Park, S.I.; Holl, M.M.B.; Su, M.; Marsh, E.N.G. Coiled-coil-mediated assembly of an icosahedral protein cage with extremely high thermal and chemical stability. J. Am. Chem. Soc. 2019, 141, 9207-9216. [CrossRef]

31. De Santis, E.; Alkassem, H.; Lamarre, B.; Faruqui, N.; Bella, A.; Noble, J.E.; Micale, N.; Ray, S.; Burns, J.R.; Yon, A.R.; et al. Antimicrobial peptide capsids of de novo design. Nat. Commun. 2017, 8, 2263. [CrossRef]

32. Kepiro, I.E.; Marzuoli, I.; Hammond, K.; Ba, X.; Lewis, H.; Shaw, M.; Gunnoo, S.B.; De Santis, E.; Łapińska, U.; Pagliara, S.; et al. Engineering chirally blind protein pseudocapsids into antibacterial persisters. ACS Nano 2020, 14, 1609-1622. [CrossRef]

33. Matsuura, K.; Watanabe, K.; Sakurai, K.; Matsuzaki, T.; Kimizuka, N. Self-assembled synthetic viral capsids from a 24-mer viral peptide fragment. Angew. Chem. Int. Ed. 2010, 49, 9662-9665. [CrossRef]

34. Matsuura, K.; Watanabe, K.; Matsushita, Y.; Kimizuka, N. Guest-binding behavior of peptide nanocapsules self-assembled from viral peptide fragments. Polymer J. 2013, 45, 529-534. [CrossRef]

35. Nakamura, Y.; Inaba, H.; Matsuura, K. Construction of artificial viral capsids encapsulating short DNAs via disulfide bonds and controlled release of DNAs by reduction. Chem. Lett. 2019, 48, 544-546. [CrossRef]

36. Fujita, S.; Matsuura, K. Inclusion of zinc oxide nanoparticles into virus-like peptide nanocapsules self-assembled from viral $\beta$-annulus peptide. Nanomaterials 2014, 4, 778-791. [CrossRef] [PubMed]

37. Fujita, S.; Matsuura, K. Encapsulation of CdTe quantum dots into synthetic viral capsids. Chem. Lett. 2016, 45, 922-924. [CrossRef]

38. Matsuura, K.; Nakamura, T.; Watanabe, K.; Noguchi, T.; Minamihata, K.; Kamiya, N.; Kimizuka, N. Self-assembly of Ni-NTA-modified $\beta$-annulus peptides into artificial viral capsids and encapsulation of His-tagged proteins. Org. Biomol. Chem. 2016, 14, 7869-7874. [CrossRef]

39. Matsuura, K.; Ueno, G.; Fujita, S. Self-assembled artificial viral capsid decorated with gold nanoparticles. Polymer J. 2015, 47, 146-151. [CrossRef]

40. Fujita, S.; Matsuura, K. Self-assembled artificial viral capsids bearing coiled-coils at the surface. Org. Biomol. Chem. 2017, 15, 5070-5077. [CrossRef]

41. Nakamura, Y.; Yamada, S.; Nishikawa, S.; Matsuura, K. DNA-modified artificial viral capsids self-assembled from DNA-conjugated $\beta$-annulus peptide. J. Pept. Sci. 2017, 23, 636-643. [CrossRef]

42. Matsuura, K.; Honjo, T. Artificial viral capsid dressed up with human serum albumin. Bioconj. Chem. 2019, 30, 1636-1641. [CrossRef]

43. Matsuura, K.; Ota, J.; Fujita, S.; Shiomi, Y.; Inaba, H. Construction of ribonuclease-decorated artificial virus-like capsid by peptide self-assembly. J. Org. Chem. 2020, 85, 1668-1673. [CrossRef]

44. Matsuura, K. Dressing up artificial viral capsids self-assembled from C-terminal-modified $\beta$-annulus peptides. Polymer J. 2020, 52, 1035-1041. [CrossRef]

45. Grigorenko, V.; Chuber, T.; Kapeliuch, Y.; Borchers, T.; Spener, F.; Egorov, A. New approaches for functional expression of recombinant horseradish peroxidase C in Escherichia coli. Biocatal. Biotransfor. 1999, 17, 359-379. [CrossRef]

46. Nicell, J.A.; Wright, H. A model of peroxidase activity with inhibition by hydrogen peroxide. Enzym. Microb. Technol. 1997, 21, 302-310. [CrossRef] 
47. Dinh, H.; Nakata, E.; Mutsuda-Zapater, K.; Saimura, M.; Kinoshita, M.; Morii, T. Enhanced enzymatic activity exerted by a packed assembly of a single type of enzyme. Chem. Sci. 2020, 11, 9088-9100. [CrossRef]

Publisher's Note: MDPI stays neutral with regard to jurisdictional claims in published maps and institutional affiliations.

(C) 2020 by the authors. Licensee MDPI, Basel, Switzerland. This article is an open access article distributed under the terms and conditions of the Creative Commons Attribution (CC BY) license (http://creativecommons.org/licenses/by/4.0/). 